\title{
The Application of Building Information Modelling Method for Carbon Emission Analysis: A Case Study of Housing in Peat Lands
}

\author{
Rudi Waluyo, Subrata Aditama K. A. Uda*, Rizki Fajrianur Akbar, Muhammad Irsyad \\ Department of Civil Engineering, Faculty of Engineering, University of Palangka Raya, Palangka Raya, Indonesia
}

Received September 9, 2021; Revised December 31, 2021; Accepted January 17, 2022

\section{Cite This Paper in the following Citation Styles}

(a): [1] Rudi Waluyo, Subrata Aditama K. A. Uda, Rizki Fajrianur Akbar, Muhammad Irsyad, "The Application of Building Information Modelling Method for Carbon Emission Analysis: A Case Study of Housing in Peat Lands, "Civil Engineering and Architecture, Vol. 10, No. 2, pp. 544-556, 2022. DOI: 10.13189/cea.2022.100213.

(b): Rudi Waluyo, Subrata Aditama K. A. Uda, Rizki Fajrianur Akbar, Muhammad Irsyad (2022). The Application of Building Information Modelling Method for Carbon Emission Analysis: A Case Study of Housing in Peat Lands. Civil Engineering and Architecture, 10(2), 544-556. DOI: 10.13189/cea.2022.100213.

Copyright $\bigcirc 2022$ by authors, all rights reserved. Authors agree that this article remains permanently open access under the terms of the Creative Commons Attribution License 4.0 International License

\begin{abstract}
The construction sector is the largest contributor to carbon emission, especially from housing development activities, which has been on high demand due to the continuous increase in the population. This study aims to analyze the amount of carbon emission produced from house building materials on peat soil, using the Building Information Modeling method. The construction of houses on peat land is different from that of hard soil, because it requires to strengthen the foundation and to minimize the load on the superstructure of the building which was performed by choosing the type of material that is suitable for the location, and is also environmentally friendly. The carbon emission was calculated using a quantitative approach, where the volume of the material used was multiplied by its emission coefficient. The volume of material was obtained using the Building Information Modeling method, while the emission coefficients were acquired by utilizing the inventory data from ICE University of Bath and several literature studies. The results showed that the types of materials that produced the largest emissions were cement, mild steel, and wood, which had 14,051.90 $\mathrm{KgCO}_{2 \mathrm{eq}} /$ house, 9,565.89 $\mathrm{KgCO}_{2 \mathrm{eq}}$ /house, and 7,865.75 $\mathrm{KgCO}_{2 \mathrm{eq}}$ /house, carbon value respectively. After redesigning the building and replacing light steel with wood, the emission reduction was $5.01 \%$ from a total of $42,523.33 \mathrm{KgCO}_{2 \mathrm{eq}}$ /house or $2,109 \mathrm{KgCO}_{2 \mathrm{eq}}$ /house with a saving of Rp. 154,397.04 or 10.87/house. Based on data from Central Bureau of Statistics of the City of Palangka Raya, the number of houses built in Palangka Raya City reached
\end{abstract}

918 units with an average building area of $45-70 \mathrm{~m}^{2}$, it is estimated to save Rp. $141,397,482.72$ or $\$ 9,978.66$. It shows the importance of environmentally friendly innovations in designs and the selection of low-emission materials, which has a positive impact on finance and climate sustainability. This finding is expected to provide insights for the government in the implementation of housing construction policies that prioritize environmental factors which reduce the level of carbon produced during the construction process and its operation.

Keywords Carbon Emissions $\left(\mathrm{CO}_{2}\right)$, Building Materials, Building Houses on Peat Lands, Building Information Modeling

\section{Introduction}

Residential buildings are one of the constructions that consume the most energy, which contribute to the amount of carbon in the atmosphere. This has been on the increase due to the high demand for housing, following the increasing population. US EPA data stated that the amount of carbon emissions in the residential and commercial sectors is $13 \%$ higher than in agriculture [1]. In the UK, the amount of gas produced from the housing section is $26 \%$ of the total emissions from all sectors [2]. Moreover, the research on embodied emissions in 
residential buildings in Australia ranks second at 14.6\%, while the largest is in construction services at $54.8 \%$ [3]. In Indonesia, the amount of energy consumption in the housing sector in the Jakarta province is $20.6 \mathrm{GJ}$, which is 5 GJ greater than that of Bandung [4]. Several studies in Indonesia stated that the amount of carbon produced in the construction of houses is on average $10-45$ tons $\mathrm{CO}_{2 \mathrm{eq}}$. Depending on the type of house and the materials used as well as the location of construction, the average increase in carbon for each type reaches above 5\% [5].

The application of greenhouse construction is to significantly reduce emissions during the life cycle of the building. A green building is a structure which from its planning, development, and maintenance is intended on protecting, and saving the natural environment. This is achieved by maintaining the quality of the air in the room, paying attention to the health of its occupants and mainly adhering to the principles of sustainable development [6]. Klufallah stated that home design with a green home/building concept reduces emissions by an average of $4-5 \%$ compared to conventional methods, where the conventional method produces emissions of $733.7 \mathrm{~kg}$ $\mathrm{CO}_{2} / \mathrm{m}^{2}$, whereas if using the green method, it is obtained at $698.01 \mathrm{~kg} \mathrm{CO}_{2} / \mathrm{m}^{2}$ [7].

Another study showed that emission reduction using this concept is approximately $35 \%$ and energy consumption efficiency is almost $50 \%$ of the total [8]. Uda, stated energy optimization and the selection of environmentally friendly construction equipment will have an impact on the amount of energy and emissions generated during the life cycle of the building [9]. The implementation of low carbon design in residential buildings in several countries reduces the amount of its emission by $10 \%$, depending on the climatic conditions and behavior of the population in that country [10].

\section{Materials and Methods}

\subsection{Building Information Modeling (BIM)}

The Life Cycle Assessment (LCA) method is mostly used by researchers to measure the level of energy and carbon consumption at each stage of construction. It is a technique applied on each construction process, including building material processing, supply chain systems, and methods of implementing development activities based on the project's life cycle [11]. However, LCA has limitations in managing information, especially in the aspect of monitoring building materials and other resources that support construction activities. Therefore, a system that is able to minimize these deficiencies is necessary, which led to the use of Building Information Modeling (BIM) method [12]. The integrated system between LCA and BIM strengthens the level of accuracy in the process of assessing the impact of construction activities on the environment [13]. It saves time in the inventory of data and also improves the results of LCA analysis at the planning stage [14].

Peng's research showed that the combined use of Ecotech and BIM methods, make it easier to calculate the amount of carbon in a building's life cycle, which was not possible with the use of the LCA concept [15]. BIM is able to facilitate the collection of information and data, in an efficient and measurable manner according to the life cycle of the building. It also includes calculating the amount of emissions obtained during the process of demolition of buildings and their waste [16]. Green BIM is a concept of combining green building with BIM, which produce a modeling system in buildings, that improve the efficiency, quality, and performance of construction projects [17]. Furthermore, optimization of energy and emissions in buildings with construction costs is carried out simultaneously using the BIM system, making it easier for planners to determine the type of efficient design to be used [18].

\subsection{Green Home Construction and Carbon Emission}

The concept of green homes (buildings) was adopted in each category of assessment, including energy efficiency which has a direct impact on reducing emissions produced during building operations [8]. The contribution of emissions from housing on average is approximately 30 $\mathrm{TonCO}_{2 \mathrm{eq}}$ per year per unit. This shows the magnitude of the impact of environmental pollution from the residential sector [19]. Moreover, the owner's commitment to reducing energy consumption at the initiation stage has an impact on the gradual decrease of emissions, starting from design, construction, operation, and demolition of the buildings [11]. Yim's research discovered that $86 \%$ of carbon emissions are generated at the operational stage of the building, namely during the renovation and maintenance [20].

Several sources of emissions from energy consumption in construction are during the material processing and distribution process. The use of construction technology that is environmental friendly in each type of house facilitates the reduction of emissions by $25 \%$ [21]. Kong's research on estimating carbon consumption in construction activities using prefabricated floor slabs discovered that, $97.5 \%$ of the gas was generated at the material production stage, while the rest was in the transportation and building processes [22]. Cement materials, hollow concrete blocks (HCB), and reinforcement bars (rebars) are materials that produce the highest carbon in construction buildings [23]. Cho showed that $78 \%$ of carbon was generated at the operational and maintenance stages. The research also discovered that concrete material was ranked the highest, with $72.7 \%$ of the total emissions from the high-rise buildings in South Korea [24]. Lu's research on hospital buildings in China discovered that $91.31 \%$ of carbon was obtained from the operational stage and reinforced concrete material ranked 
the highest in generating emissions during the building's life cycle [25]. The selection of natural building materials and designs, which utilizes photovoltaic lighting has great potential in reducing buildings' carbon emissions [26].

\subsection{Building Construction on Peat Lands}

Peat land is classified as a soft soil, because most of its constituent comes from organic material, which was produced from plant remains that were not fully decomposed, due to water-saturated environment and lack of nutrients. In Indonesia, the area of peat lands is approximately 14.9 million hectares, of which $35 \%$ (2.7 million hectares) is located on the Kalimantan Island, especially the Central Kalimantan Province [27]. However, some problems are experienced on the peat land, include drainage issues, site investigation practices, monitoring, and poor construction guidelines [28]. The soft soil characteristics, such as low carrying capacity, stability, and high groundwater level affect the land, lead to its requirements of special construction methods for building foundation structures [29].

Wang's research stated that peat soil is strengthened by utilizing compacted gravel piles under building foundations, as well as in its maintenance [30]. To reduce the risk of construction failure, the weight of the building materials should be decreased or the peat be dewatered to improve its technical engineering properties and stability [31]. The stability and strength of peat are also increased by utilizing waste ash from agricultural products, materials manufacturing companies, waste treatment, and processing composite materials [32].

Peat drainage is one way to structurally strengthen the stability of the subgrade as a place for foundations, but this will have an impact on the high risk of increasing the potential for fires that produce higher carbon. The use of the cerucuk galam foundation is an effort to keep the peat wet but is able to increase the stability of the soil as the basis for building houses. This construction adopts the traditional house buildings (Huma Betang) of the Dayak tribe, most of which use high wooden poles as the foundation of the house.

The high carbon emission from the construction of houses has a direct impact on the increase in the earth's temperature. Therefore, the government launched the construction of 1 million houses for the needs of the community starting 2014 and data from the Ministry of Public Works and Housing (PUPR) showed the progression of this project with 856,758 units in December 2020, throughout the territory of the Republic of Indonesia, of which 918 units were built in Palangka Raya City. The proportion of housing construction carried out by the government is $77 \%$ for low-income/poor people and the remaining $23 \%$ for non-low/middle-income people [33]. Assuming the process of building a house produces $1000 \mathrm{KgCO}_{2 \mathrm{eq}}$ of carbon, then the amount emitted based on these data is $918,000 \mathrm{KgCO}_{2 \mathrm{eq}}$ or about 918 tonCO $\mathrm{Ce}_{2 \mathrm{eq}}$ from 918 houses build in Palangka Raya. When this is reduced by 100 $\mathrm{KgCO}_{2 \text { eq }}$ per unit, then the total emission that has been successfully decreased is $9,180 \mathrm{KgCO}_{2}$ eq or about 9.18 $\mathrm{TonCO}_{2 \text { eq }}$. The above assumption shows the importance of engineering design and the selection of environmentally friendly materials to reduce carbon during construction, especially in the housing sector.

\subsection{Research Methods}

This study was conducted in the city of Palangka Raya, Central Kalimantan Province, Indonesia. This was chosen because most of the housing in these locations is on the peat land area, with an average depth of 1-5 $\mathrm{m}$ and 0.25 $1 \mathrm{~cm}$ groundwater level above the surface. Figure 1 shows the initial design of the building, using river stone foundation construction and the roof truss which was made with lightweight steel. 

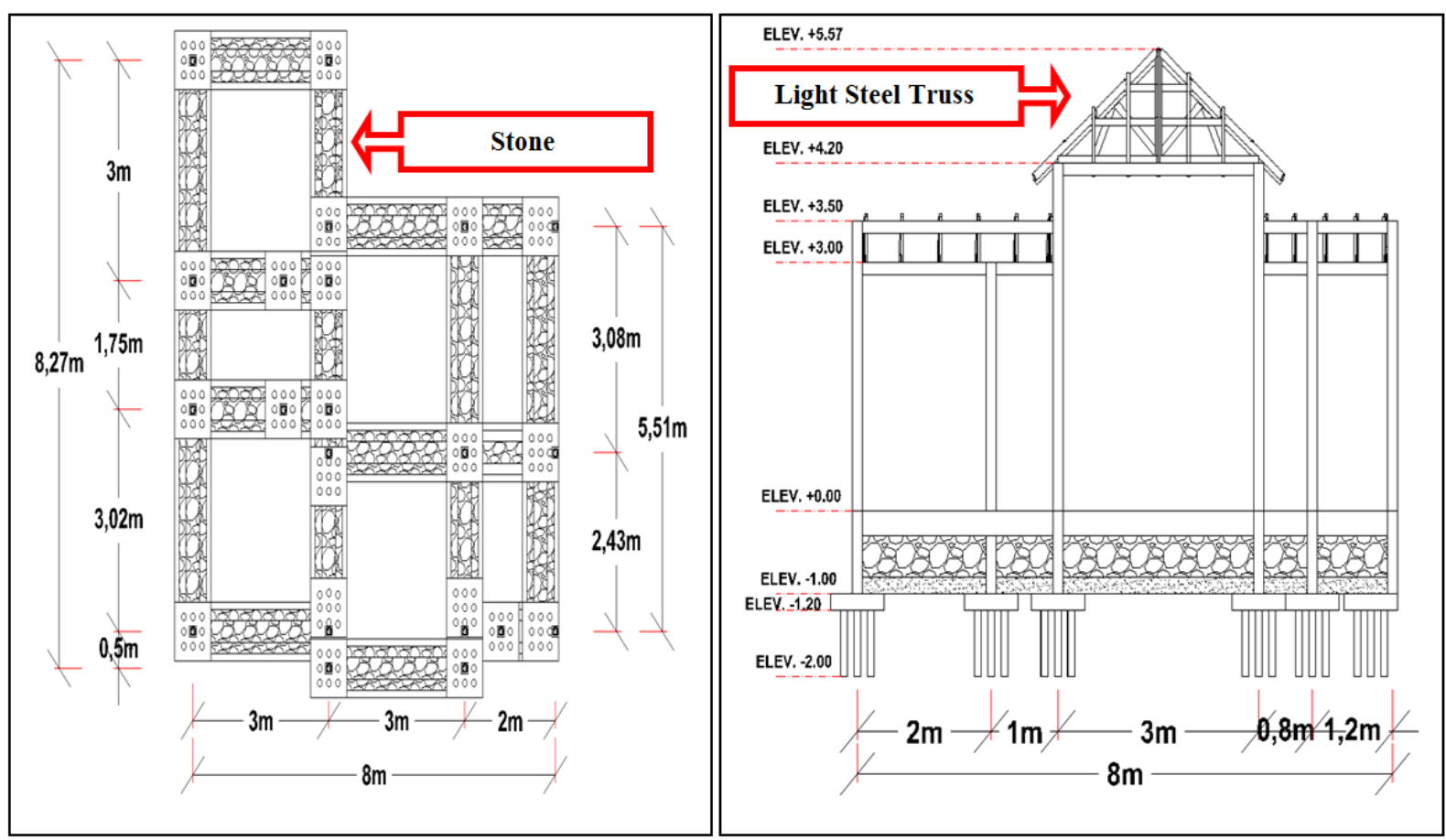

Figure 1. Original Design of House Building
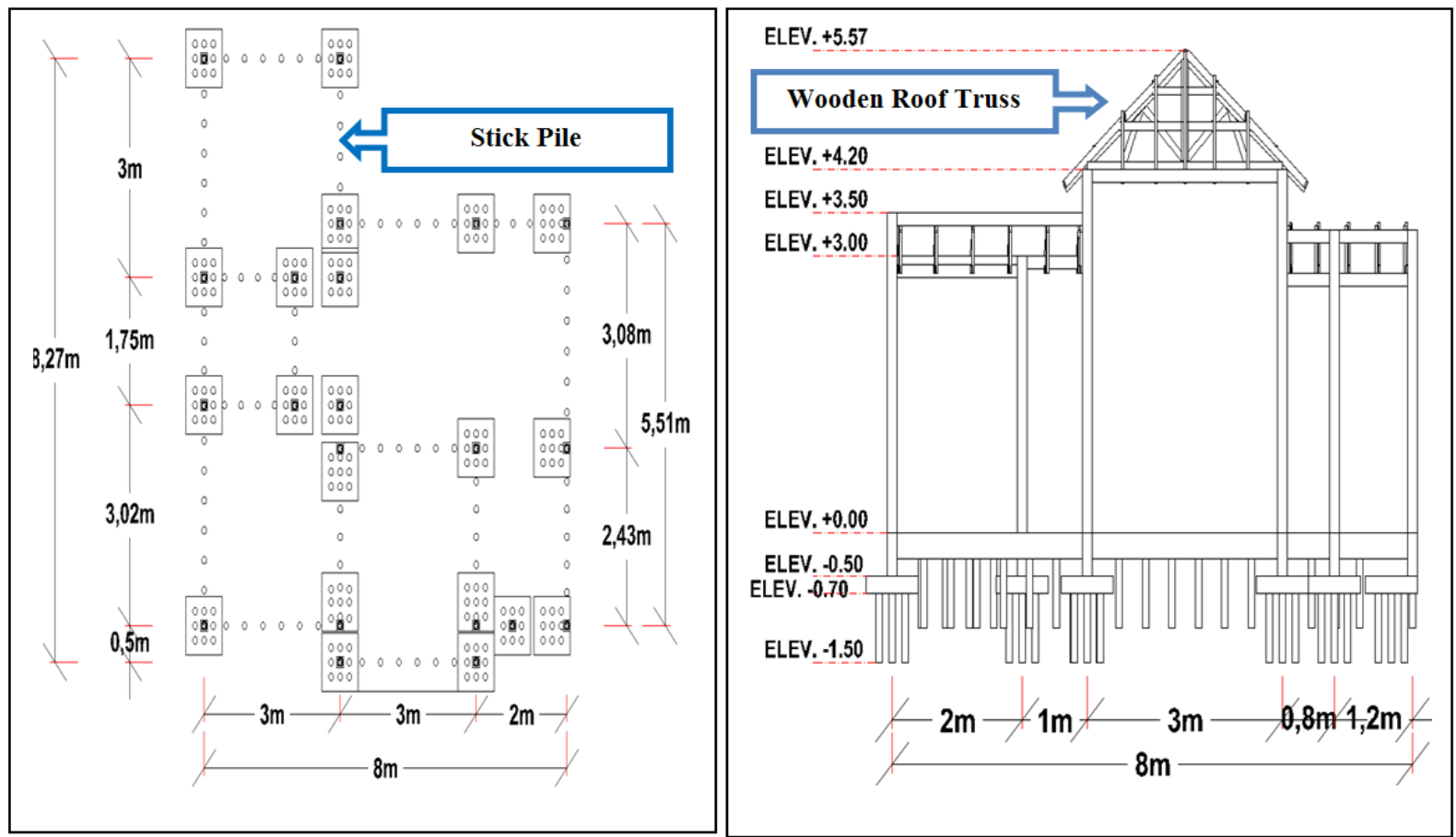

Figure 2. House Building Redesign with Low Carbon Concept

This research takes a case study on a simple house building in the city of Palangka Raya. In general, the average house building in this city has an area of $45-70$ $\mathrm{m}^{2}$, in this study we made a house plan with an area of $52.36 \mathrm{~m}^{2}$, where the house is currently under construction. The roof used is a pyramid roof truss structure with an area of $16.53 \mathrm{~m}^{2}$ in the middle, while on the left and right sides; it uses a right triangle frame structure with an area of $24.81 \mathrm{~m}^{2}$ and $11.02 \mathrm{~m}^{2}$, respectively. Figure 2 shows the redesign after the implementation of the low emission building concept, where the foundation used is cerucuk galam wood with a distance of $10-20 \mathrm{~cm}$ which is driven 1-2 $\mathrm{m}$ from the ground surface. Supriyati's research states that Gelam wood as a house pile in swamp soil has strength for more than 30 years in peat soil; this is because Galam wood contains silica if it is piled up or 
plugged into peat soil it will increase the wood's hardness. So the longer the galam wood is in the peat soil, the stronger it will be [34].

This case study aims to find out how much carbon is generated by building houses on shallow peatlands. However, this amount of carbon will vary based on the type of house, building area, material and peat depth. For this reason, further and in-depth research is needed to obtain the average amount of carbon produced.

The carbon emissions were calculated in units of $\mathrm{KgCO}_{2} / \mathrm{Kg}$ or based on their functional units using $\mathrm{KgCO}_{2} / \mathrm{m}^{3}$ or $\mathrm{kgCO}_{2} / \mathrm{m}^{2}$ material, where each material has a different carbon emission value [35]. The formula for calculating the carbon emissions based on material consumption is as follows:

$$
\mathrm{EC}=\mathrm{Vm} \times \mathrm{CEC}
$$

Where $\mathrm{EC}$ is the amount of carbon emissions in the material using $\mathrm{KgCO}_{2}$ units. $\mathrm{Vm}$ is the total volume for each type of material used $\left(\mathrm{m}^{3}\right)$, when the volume unit is different, it is necessary to convert it first to the unit density of the material. CEC is the Carbon Emission Coefficient that was obtained from Bath University inventory data in units $\left(\mathrm{KgCO}_{2} / \mathrm{Kg}\right)$. This unit refers to the carbon value of one material in units per $\mathrm{Kg}$, from this unit value it will be multiplied by the volume of the material from the building quantity calculation so as to produce the total amount in $\mathrm{KgCO}_{2}$ units. Then when viewed from the building area, the total carbon divided by the area $\left(\mathrm{KgCO}_{2} / \mathrm{m}^{2}\right)$. The coefficient of the value of the emission content in the material also used inventory data from Bath University [35]. Innovations in building design and the selection of environmentally friendly materials have the ability to reduce the carbon produce. Table 1 shows the comparison between the original design and the redesign.

Several scenarios are carried out in this study to reduce the amount of emissions generated from construction methods and materials:

- Making changes to the foundation design using galam wood and removing river stones. This material replacement aims to strengthen the foundation structure on peat soil by increasing soil stability using galam wood.

- The foundation used is in the form of a footplate by placing an iron frame on top of galam wood poles as subgrade reinforcement.

- Replacing the type of light steel material on the roof structure with low-emission wood materials.

\section{Results and Discussion}

The optimization of the amount of carbon in this study was carried out by redesigning the initial building structure, especially the roof truss. Where the initial planning utilized a mild steel frame with a carbon value of $1.91 \mathrm{KgCO}_{2} / \mathrm{Kg}$, it was replaced with a wooden frame that had $0.45 \mathrm{KgCO}_{2} / \mathrm{Kg}$ carbon value. Also, the design of the river stone foundation was replaced with wooden piles, Cerucuk, which is a type of Galam wood. The use of galam wood to improve the stability of peat soil is one of the efforts to keep the condition of the peat soil wet, where previously many people used ordinary excavation construction as river stone foundations. This local construction method can cause the peat soil to dry out and besides that the foundation becomes unstable and easily damaged and the walls are easy to crack.

Table 1. Comparison between original design and re-design

\begin{tabular}{|c|c|c|}
\hline Research Items & Original Design & Re-Design \\
\hline \multirow[b]{2}{*}{ Foundation } & $\begin{array}{l}\text { The main material uses a mixture of river stone and } \\
\text { concrete }\end{array}$ & The main materials use Galam Wood and Concrete \\
\hline & $\begin{array}{l}\text { The method of making stone foundations is done by } \\
\text { making excavations as deep as } 0.5-1 \mathrm{~m} \text { and filled } \\
\text { with a mixture of river stone and concrete where the } \\
\text { column is placed on a river stone foundation. } \\
\text { Construction of this type of foundation often suffers } \\
\text { damage, especially in areas with a peat depth of more } \\
\text { than } 2 \mathrm{~m} \text { which results in a decrease in the foundation } \\
\text { and causes cracks in the walls of the building. For this } \\
\text { reason, it is necessary to have stability in the soil } \\
\text { under the stone laying foundation. }\end{array}$ & $\begin{array}{l}\text { Methods The construction of galam wood piles is } \\
\text { carried out by driving galam wood poles as deep as } \\
1-2 \mathrm{~m} \text { at a distance of } 10-20 \mathrm{~cm} \text { between the piles in } \\
\text { the foundation excavation. Then tied with concrete } \\
\text { casting. Column foundation directly on galam wood. } \\
\text { Galam wood is a plant that lives in peat areas, where it } \\
\text { is often used as a foundation for road buildings and as } \\
\text { a pillar for pedestrian bridges on peat soil in the city of } \\
\text { Palangka Raya. Galam wood if it is in peat soil the } \\
\text { longer, it will get stronger [34] }\end{array}$ \\
\hline \multirow[b]{2}{*}{ Roof } & The main material uses Lightweight Steel Frame & The main material uses a wooden frame \\
\hline & $\begin{array}{l}\text { The lightweight steel roof truss construction method } \\
\text { has a pyramidal shape, with a square at the bottom and } \\
\text { a cone at the top. So that from the front the roof looks } \\
\text { to have a triangular shape. }\end{array}$ & $\begin{array}{l}\text { The type of frame structure is the same as the original } \\
\text { design, only the material has been replaced with class } \\
\text { I wood. }\end{array}$ \\
\hline
\end{tabular}




\subsection{Carbon Emission Estimation based on Type of Building Material}

Figure 3 shows the comparison between the total amount of carbon produced by the type of material used in the initial planning and in the redesign of the house in units of $\mathrm{KgCO}_{2 \mathrm{eq}}$ of carbon. It was observed that 6 materials dominated the amount of carbon produced in building houses. The first was the cement, which produced the highest amount of carbon, at 14,051.90 $\mathrm{KgCO}_{2 \text { eq }}$ for the initial plan and $11,377.64 \mathrm{KgCO}_{2 \mathrm{eq}}$ after the redesign, i.e., it emitted an average of $28 \%-34 \%$ of the total carbon in the building. The second-largest rank was the wood material at 7,865.75 $\mathrm{KgCO}_{2 \mathrm{eq}}$ before redesigning and after this process, it was 9,888.71 $\mathrm{KgCO}_{2 \text { eq }}$, with the average yield of $18 \%-24 \%$. Next was the Light Steel (Metal Hollow) material for the roof truss with $9,565.89 \mathrm{KgCO}_{2 \mathrm{eq}}$ or $22 \%$ in the initial planning, while in the redesign, it was replaced with a wood material. Then the next rank was the Steel material at
2,754.93 $\mathrm{KgCO}_{2 \mathrm{eq}}$ and 3,512.46 $\mathrm{KgCO}_{2 \mathrm{eq}}$ after redesign, i.e., an average yield of $6 \%-9 \%$. Furthermore, Conblock tile material with $2,283.84 \mathrm{KgCO}_{2 \text { eq, }}$ was replaced with metal roof with $1,063.33 \mathrm{KgCO}_{2 \text { eq }}$ of carbon. And lastly, sand, plywood, and other materials had an average below $1,200 \mathrm{KgCO}_{2 \mathrm{eq}}$.

The high amount of carbon produced by cement and mild steel shows that these materials are major contributors to building emissions. This is consistent with several studies, where cement and iron are the main carbon-producing elements in construction buildings [7; $23 ; 24 ; 25]$. Sygros stated that cement material dominates with an average of $60 \%$ and iron by $30 \%$ of the total buildings in residential structure in Greece [36]. House buildings which used concrete produced an average of $523.6 \mathrm{KgCO}_{2 \mathrm{eq}} / \mathrm{m}^{2}$ of carbon while, the use of wood as the main material, produced $508.8 \quad \mathrm{KgCO}_{2 \mathrm{eq}} / \mathrm{m}^{2}$. This shows that concrete or cement materials have the potential to produce more carbon than wood [37].

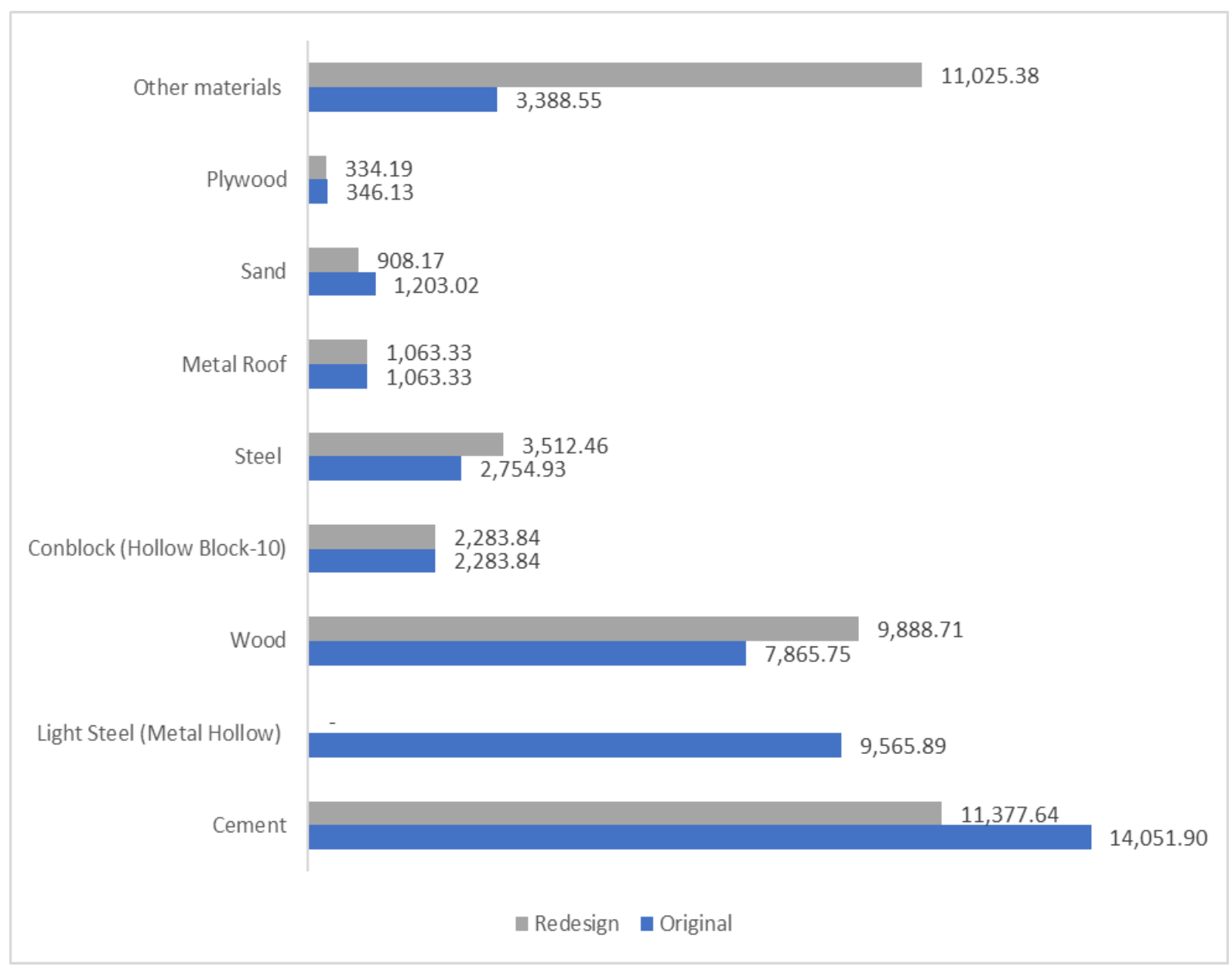

Figure 3. Comparison of Estimated Carbon Emissions based on Material Type $\left(\mathrm{KgCO}_{2 \mathrm{eq}}\right)$ 


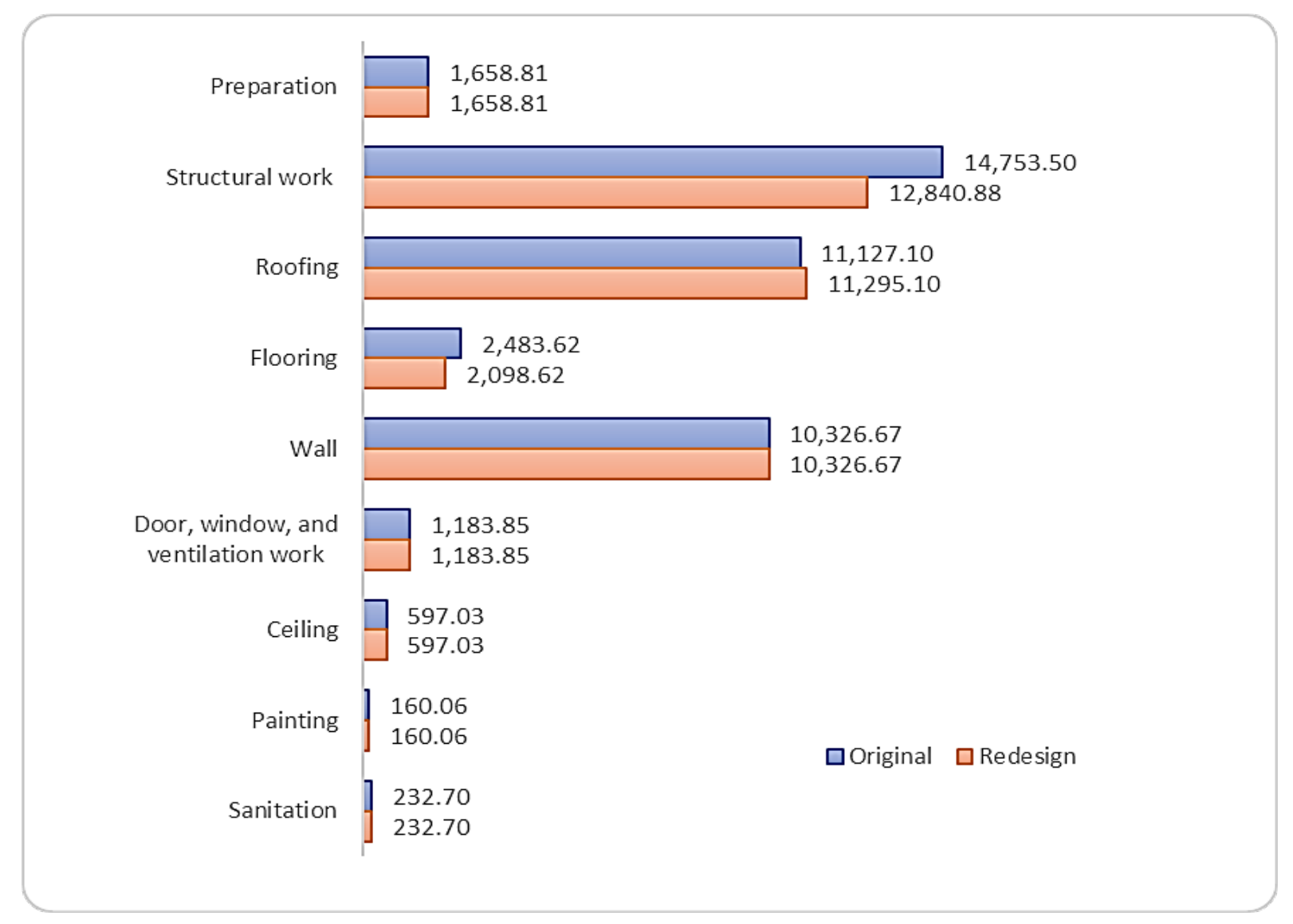

Figure 4. Comparison of Carbon Estimates based on Type of Work $\left(\mathrm{KgCO}_{2 \mathrm{eq}}\right)$

\subsection{Carbon Emission Estimation Based on Type of Works}

Figure 4 shows the comparison between the total amount of carbon produced by the type of work carried out, during the initial planning and redesign of the house building in $\mathrm{KgCO}_{2 \mathrm{eq}}$ units of carbon. Structural work produced the highest carbon with above $12,000 \mathrm{KgCO}_{2 \mathrm{eq}}$, while the rooftop job was the second with an average of $11,000 \mathrm{KgCO}_{2 \mathrm{eq}}$. Furthermore, wall work was in the third place with a total carbon of $10,326.67 \mathrm{KgCO}_{2 \text { eq }}$. While other works, such as flooring, building preparation, as well as door, window, and ventilation work, produced an average of $1,000-2,500 \mathrm{KgCO}_{2 \text { eq. }}$ Lastly, the smallest amount of carbon was generated from painting work at about $160.06 \mathrm{KgCO}_{2 e q}$, followed by sanitation and ceiling work with 232.70 and $597.03 \mathrm{KgCO}_{2 \mathrm{eq}}$, respectively.

This result is in accordance with Caldas' research which discovered that wall work produced $77 \%$ of the total carbon emitted during construction work [38]. However, Kumanayake discovered that wall work with clay brick material emanated $70 \%$ carbon [39]. Therefore, Lou suggested the use of earth brick as the main material for the walls of the house, because of its low carbon contribution, which is $10.4 \%$ smaller than other materials [26].

\subsection{Estimation of Carbon Emission Reduction}

Figure 5 shows the comparison of the total carbon produced in both designs. The total carbon emission in the original design of the building was $42,523.33 \mathrm{KgCO}_{2 \mathrm{eq}}$ per house, while after re-designing it produced 40,393.72 $\mathrm{KgCO}_{2 \text { eq }}$ per house. The estimation results showed a decrease in carbon emissions of about $2,129.61 \mathrm{KgCO}_{2 \mathrm{eq}}$ per house. This proves that prioritizing the concept of green building and using environmentally friendly building materials during construction design reduce carbon emissions.

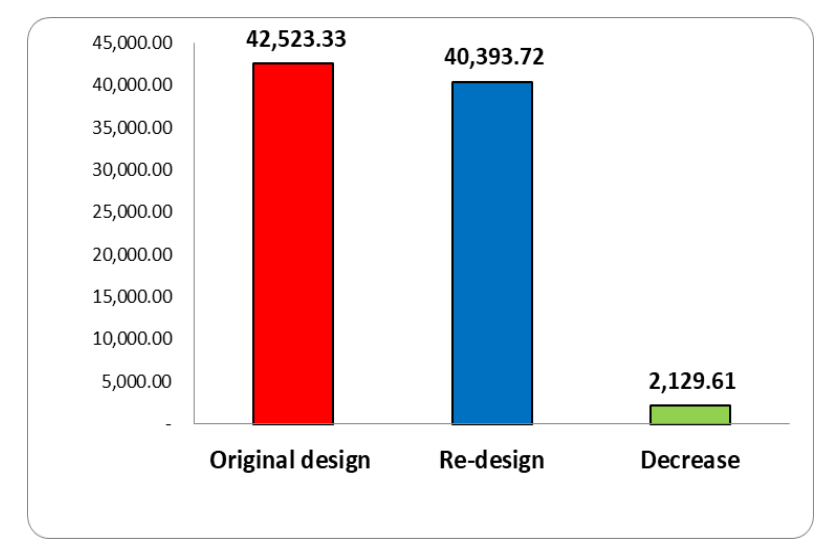

Figure 5. Comparison of Total Carbon $\left(\mathrm{KgCO}_{2 \mathrm{eq}}\right)$ 
Based on the amount of reduction, the efficiency cost was obtained by taking the standard value of the 2020 carbon price of Rp. 72,500 per tonne of $\mathrm{CO}_{2}$, which produced Rp. $154,396.73$ or $\$ 10.87$ per housing or in other words, it is estimated that each house will save approximately 2 tons $\left(2,129.61 \mathrm{Kg} \mathrm{CO}_{2 \mathrm{eq}}\right.$ or 2.1 tons) per house. This study discovered that green concept design and the selection of low-carbon and environmentally friendly materials have a positive impact on the environment and also have financial benefits, as observed from the large amount of carbon reduction. This is in accordance with Elias' research which stated that $77 \%$ of respondents from housing developers in Malaysia prioritize the use of green building and environmentally friendly technology while planning house construction [19]. Therefore, providing awareness for the community involved in planning house construction in order for them to pay attention to environmental factors reduces carbon emissions in the atmosphere, and climate sustainability is maintained.

\section{Conclusions}

The housing sector is one of the largest contributors to carbon emissions in the atmosphere. This is due to the increase in population and the high need for private housing. This study discovered that carbon optimization is carried out using environmentally friendly designs and choosing the type of material with the smallest carbon value without reducing the aesthetics of the building. Especially when building houses on peat soil, a foundation type is needed to maintain the stability of the sub-grade and the strength of the building structure. Furthermore, the use of Galam wood which has high resistance in wet and acidic areas, such as peat lands reinforced the foundation of buildings compared to using river stone. The area of peatland used as a settlement is estimated at 1000 hectares to meet the needs of around 200,000 housing units with an average of $50 \mathrm{~m}^{2}$ per house, where the population of Palangka Raya city in 2020 will reach 293,500 people [40]. The results showed that the total amount of carbon efficiency after the redesign was $2,129.61 \mathrm{KgCO}_{2 \text { eq }}$ per house or $44.73 \mathrm{KgCO}_{2 \mathrm{eq}} / \mathrm{m}^{2}$ with an area of $52.36 \mathrm{~m}^{2}$ per house and the value of financial gain obtained was Rp. $154,396.73$ or $\$ 10.87$ per housing unit. Therefore, optimal planning by prioritizing environmental friendly elements has a direct impact on cost efficiency.

\section{Acknowledgments}

We would like to thank Engineering Faculty, Civil Engineering Department, the University of Palangka Raya for their assistance in facilitating and funding this research. 


\section{Appendix A}

Table Appendix A: Calculation of carbon emissions in house construction using building information model (BIM)

\begin{tabular}{|c|c|c|c|c|c|c|c|c|c|c|}
\hline \multirow{3}{*}{ No } & \multirow{3}{*}{ Type of Material } & \multicolumn{2}{|c|}{ Volume } & \multirow{3}{*}{ Units } & \multirow{2}{*}{$\begin{array}{l}\text { Density } \\
\text { Material }\end{array}$} & \multicolumn{2}{|c|}{ Material Volume } & \multirow{2}{*}{$\begin{array}{c}\text { Emission Carbon } \\
\text { Coefficient }\end{array}$} & \multicolumn{2}{|c|}{ Emission Amount } \\
\hline & & \multirow{2}{*}{$\begin{array}{c}\text { Original } \\
\text { Design }\end{array}$} & \multirow{2}{*}{ Re-Design } & & & $\begin{array}{c}\text { Original } \\
\text { Design }\end{array}$ & Re-Design & & $\begin{array}{c}\text { Original } \\
\text { Design }\end{array}$ & Re-Design \\
\hline & & & & & (Kg/M3) & $(\mathrm{Kg})$ & $(\mathrm{Kg})$ & $\left(\mathrm{KgCO}_{2} / \mathrm{Kg}\right)$ & $\left(\mathrm{KgCO}_{2}\right)$ & $\left(\mathrm{KgCO}_{2}\right)$ \\
\hline 1 & Water & 2717 & 2670 & ltr & 1 & 2717 & 2670 & 0.03 & 81.51 & 80 \\
\hline 2 & $\begin{array}{l}\text { Accessories } \\
\text { (reinforcement, } \\
\text { welding, etc.) }\end{array}$ & 423 & 423 & 1s & - & - & - & - & - & - \\
\hline 3 & Fiberglass tub & 1 & 1 & unit & 2000 & 1 & 1 & 1.53 & 1.53 & 1.53 \\
\hline 4 & Class I. Wooden Beams & 1 & 1 & $\mathrm{~m}^{3}$ & 1000 & 1000 & 1.000 & 0.45 & 450 & 450 \\
\hline 5 & $\begin{array}{c}\text { Class II. Wooden } \\
\text { Beams } \\
\end{array}$ & 2 & 2 & $\mathrm{~m}^{3}$ & 850 & 1700 & 1700 & 0.45 & 765 & 765 \\
\hline 6 & Anchor Iron (Ø 8 mm) & 59 & 59 & $\mathrm{~kg}$ & 7850 & 59 & 59 & 1.71 & 100.89 & 100.89 \\
\hline 7 & Steel & 1432 & 1871 & $\mathrm{~kg}$ & 7850 & 1432 & 1871 & 1.71 & $2.448,72$ & 3199.41 \\
\hline 8 & Base paint & 42 & 42 & $\mathrm{~kg}$ & 1.5 & 42 & 42 & 0.53 & 22.26 & 22.26 \\
\hline 9 & Finishing paint & 109 & 109 & $\mathrm{~kg}$ & 1.5 & 109 & 109 & 1.06 & 115.54 & 115.54 \\
\hline 10 & $\begin{array}{c}\text { Wooden piles, (Cerucuk } \\
\text { Galam) } \\
(\varnothing 8-10 \mathrm{~cm}) \text {-length } 400 \\
\mathrm{~cm})\end{array}$ & 189 & 270 & unit & 720 & 4272.91 & 6104.16 & 0.45 & 1922.81 & 2746.87 \\
\hline 11 & River stone & 24 & - & $\mathrm{m}^{3}$ & 1500 & 36000 & - & 0.017 & 612 & - \\
\hline 12 & Toilet seat & 1 & 1 & unit & 2500 & 40 & 40 & 1.48 & 59.20 & 59.20 \\
\hline 13 & $\begin{array}{l}\text { Wooden piles, } \\
(\varnothing 8-10 \mathrm{~cm}) \text { - length } 4 \mathrm{~m}\end{array}$ & 180 & 169 & unit & 720 & 4069.44 & 3820.75 & 0.45 & 1831.25 & 1719.34 \\
\hline 14 & Window hinges & 20 & 20 & unit & 7500 & 14 & 14 & 6.15 & 86.10 & 86.10 \\
\hline 15 & Door hinges & 18 & 18 & unit & 7500 & 12.60 & 12.6 & 6.15 & 77.49 & 77.49 \\
\hline 16 & Floor drain & 1 & 1 & unit & 1.4 & 0.35 & 0.35 & 2.53 & 0.89 & 0.89 \\
\hline 17 & Metal Roof & 102 & 102 & $\mathrm{~m}^{3}$ & 7135 & 291.11 & 291 & 3.31 & 963.57 & 963.57 \\
\hline 18 & Grendel key & 28 & 28 & unit & 7850 & 2.30 & 2.30 & 1.91 & 4.39 & 4,39 \\
\hline 19 & Gypsum board & 21 & 21 & sheet & 2787 & 1517.02 & 1517.02 & 0.12 & 182.04 & 182.04 \\
\hline 20 & Window handle & 10 & 10 & unit & 7850 & 3 & 3 & 1.91 & 5.73 & 5.73 \\
\hline
\end{tabular}




\begin{tabular}{|c|c|c|c|c|c|c|c|c|c|c|}
\hline \multirow{3}{*}{ No } & \multirow{3}{*}{ Type of Material } & \multicolumn{2}{|c|}{ Volume } & \multirow{3}{*}{ Units } & \multirow{2}{*}{$\begin{array}{c}\text { Density } \\
\text { Material }\end{array}$} & \multicolumn{2}{|c|}{ Material Volume } & \multirow{2}{*}{$\begin{array}{c}\text { Emission Carbon } \\
\text { Coefficient }\end{array}$} & \multicolumn{2}{|c|}{ Emission Amount } \\
\hline & & \multirow{2}{*}{$\begin{array}{c}\text { Original } \\
\text { Design }\end{array}$} & \multirow[t]{2}{*}{ Re-Design } & & & $\begin{array}{c}\text { Original } \\
\text { Design }\end{array}$ & Re-Design & & $\begin{array}{c}\text { Original } \\
\text { Design }\end{array}$ & Re-Design \\
\hline & & & & & (Kg/M3) & $(\mathrm{Kg})$ & $(\mathrm{Kg})$ & $\left(\mathrm{KgCO}_{2} / \mathrm{Kg}\right)$ & $\left(\mathrm{KgCO}_{2}\right)$ & $\left(\mathrm{KgCO}_{2}\right)$ \\
\hline 21 & $\begin{array}{l}\text { Conblock (Hollow } \\
\text { Block/HB-10) }\end{array}$ & 2600 & 2600 & unit & 1800 & 37440 & 37440 & 0.061 & 2283.84 & 2283.84 \\
\hline 22 & Glass Thickness $5 \mathrm{~mm}$ & 8 & 8 & $\mathrm{~m}^{2}$ & 2579 & 103.16 & 103.16 & 0.85 & 87.69 & 87.69 \\
\hline 23 & Window hook & 20 & 20 & unit & 7850 & 4 & 4 & 1.91 & 7.64 & 7.64 \\
\hline 24 & Wood beam $(5 \times 7 \mathrm{~cm})$ & 1 & 1 & $\mathrm{~m}^{3}$ & 850 & 850 & 850 & 0.45 & 382.50 & 382.50 \\
\hline 25 & wire & 21 & 27 & $\mathrm{~kg}$ & 7850 & 21 & 27 & 1.71 & 35.91 & 46.17 \\
\hline 26 & $\begin{array}{c}\text { Class III. Wooden } \\
\text { Beams }\end{array}$ & 10 & 10 & $\mathrm{~m}^{3}$ & 550 & 5500 & 5500 & 0.45 & 2475 & 2475 \\
\hline 27 & Gravel (maks.30 mm) & 13002 & 12772 & $\mathrm{~kg}$ & 1800 & 13002 & 12772 & 0.017 & 221.03 & 217.12 \\
\hline 28 & Aggregate & 1 & 1 & $\mathrm{~m}^{3}$ & 1800 & 1800 & 1800 & 0.017 & 30.60 & 30.60 \\
\hline 29 & Water faucet & 4 & 4 & $\mathrm{~m}$ & 1.4 & 0.20 & 0.2 & 2.53 & 0.51 & 0.51 \\
\hline 30 & Door locks & 1 & 1 & unit & 7500 & 1.40 & 1.4 & 6.15 & 8.61 & 8.61 \\
\hline 31 & Wood glue & 4 & 4 & $\mathrm{~kg}$ & 550 & 4 & 4 & 0.65 & 2.60 & 2.60 \\
\hline 32 & Formwork Oil & 22 & 21 & $1 \operatorname{tr}$ & 0.87 & 19.14 & 18.27 & 1.07 & 20.48 & 19.55 \\
\hline 33 & Top metal roof & 88 & 88 & unit & 7135 & 30.14 & 30 & 3.31 & 99.76 & 99.76 \\
\hline 34 & Nail $(5-10) \mathrm{mm}$ & 17 & 17 & $\mathrm{~kg}$ & 7850 & 17 & 17 & 1.71 & 29.07 & 29.07 \\
\hline 35 & $\operatorname{Nail}(5-12) \mathrm{mm}$ & 33 & 31 & $\mathrm{~kg}$ & 7850 & 33 & 31 & 1.71 & 56.43 & 53.01 \\
\hline 36 & Nail $(10 \mathrm{~cm})$ & 2 & 2 & $\mathrm{~kg}$ & 7850 & 2 & 2 & 1.77 & 3.54 & 3.54 \\
\hline 37 & Nail $(5 \mathrm{~cm}$ and $7 \mathrm{~cm})$ & 8 & 8 & $\mathrm{~kg}$ & 7850 & 8 & 8 & 1.71 & 13.68 & 13.68 \\
\hline 38 & $\operatorname{Nail}(7 \mathrm{~cm}-10 \mathrm{~cm})$ & 12 & 12 & $\mathrm{~kg}$ & 7850 & 12 & 12 & 1.71 & 20.52 & 20.52 \\
\hline 39 & Nail (1/2" - 1") & 20 & 20 & $\mathrm{~kg}$ & 7850 & 20 & 20 & 1.71 & 34.20 & 34.20 \\
\hline 40 & Nail (2" - 3") & 1 & 1 & $\mathrm{~kg}$ & 7850 & 1 & 1 & 1.71 & 1.71 & 1.71 \\
\hline 41 & Screw nail & 7 & 7 & $\mathrm{~kg}$ & 7850 & 7 & 7 & 1.71 & 11.97 & 11.97 \\
\hline 42 & Wooden board & 3 & 3 & $\mathrm{~m}^{3}$ & 1000 & 3000 & 3000 & 0.45 & 1350 & 1350 \\
\hline 43 & Sand & 9603 & 9433 & $\mathrm{~kg}$ & 1400 & 9603 & 9433 & 0.005 & 48.02 & 47.17 \\
\hline 44 & Sand & 1 & 1 & $\mathrm{~m}^{3}$ & 1400 & 1400 & 1400 & 0.005 & 7 & 7 \\
\hline 45 & River sand & 105 & 94 & $\mathrm{~m}^{3}$ & 1400 & 147000 & 131600 & 0.005 & 735 & 658 \\
\hline 46 & Backfill sand & 59 & 28 & $\mathrm{~m}^{3}$ & 1400 & 82600 & 39200 & 0.005 & 413 & 196 \\
\hline 47 & Equipment & 12 & 12 & $\%$ & 0.0 & - & - & - & - & - \\
\hline
\end{tabular}




\begin{tabular}{|c|c|c|c|c|c|c|c|c|c|c|}
\hline \multirow{3}{*}{ No } & \multirow{3}{*}{ Type of Material } & \multicolumn{2}{|c|}{ Volume } & \multirow{3}{*}{ Units } & \multirow{2}{*}{$\begin{array}{l}\text { Density } \\
\text { Material }\end{array}$} & \multicolumn{2}{|c|}{ Material Volume } & \multirow{2}{*}{$\begin{array}{c}\text { Emission Carbon } \\
\text { Coefficient }\end{array}$} & \multicolumn{2}{|c|}{ Emission Amount } \\
\hline & & \multirow{2}{*}{$\begin{array}{c}\text { Original } \\
\text { Design }\end{array}$} & \multirow{2}{*}{ Re-Design } & & & $\begin{array}{c}\text { Original } \\
\text { Design }\end{array}$ & Re-Design & & $\begin{array}{c}\text { Original } \\
\text { Design }\end{array}$ & Re-Design \\
\hline & & & & & (Kg/M3) & $(\mathrm{Kg})$ & $(\mathrm{Kg})$ & $\left(\mathrm{KgCO}_{2} / \mathrm{Kg}\right)$ & $\left(\mathrm{KgCO}_{2}\right)$ & $\left(\mathrm{KgCO}_{2}\right)$ \\
\hline 48 & 2' PVC Pipe & 8 & 8 & $\mathrm{~m}$ & 1.4 & 20.66 & 20.66 & 2.5 & 51.64 & 51.64 \\
\hline 49 & 3/4' PVC Pipe & 15 & 15 & $\mathrm{~m}$ & 1.4 & 12.93 & 12.93 & 2.5 & 32.33 & 32.33 \\
\hline 50 & 4' PVC Pipe & 4 & 4 & $\mathrm{~m}$ & 1.4 & 34.64 & 34.64 & 2.5 & 86.61 & 86.61 \\
\hline 51 & Plamir & 42 & 42 & $\mathrm{~kg}$ & 1.7 & 42 & 42 & 0.53 & 22.26 & 22.26 \\
\hline 52 & Plywood (thick. 9mm) & 29 & 28 & sheet & 550 & 427.32 & 412.58 & 0.81 & 346.13 & 334.19 \\
\hline 53 & $\begin{array}{l}\text { Hollow metal frame } \\
(1 \mathrm{x} 40.40 .2 \mathrm{~mm})\end{array}$ & 423 & 423 & $\mathrm{~m}$ & 7400 & 5008.32 & 5008.32 & 1.91 & 9565.89 & 9565.89 \\
\hline 54 & Sealant & 1 & 1 & tube & 1020 & 0.35 & 0.35 & 0.2 & 0.07 & 0.07 \\
\hline 55 & Seal tape & 1 & 1 & unit & 1.4 & - & - & 2.53 & - & - \\
\hline 56 & Cement & 16850 & 13628 & $\mathrm{~kg}$ & 3150 & 16850 & 13628 & 0.83 & 13985.50 & 11311.24 \\
\hline 57 & Cement & 1 & 1 & $1 \mathrm{~s}$ & - & - & - & 0.83 & - & - \\
\hline 58 & Color cement & 80 & 80 & $\mathrm{~kg}$ & 3150 & 80 & 80 & 0.83 & 66.40 & 66.40 \\
\hline 59 & Roof zinc & 14 & 14 & sheet & 7135 & 35.96 & 35.96 & 3.31 & 119.03 & 119.03 \\
\hline 60 & Zinc plate & 3 & 3 & sheet & 7135 & 18.49 & 18.49 & 3.31 & 61.21 & 61.21 \\
\hline 61 & $\begin{array}{c}\text { Gray floor tiles }(40 \times 40 \\
\mathrm{cm})\end{array}$ & 392 & 392 & box & 2200 & 413.95 & 413.95 & 0.13 & 53.81 & 53.81 \\
\hline 62 & $\begin{array}{c}\text { Ceramic floor tiles } \\
(20 \times 20 \mathrm{~cm})\end{array}$ & 5 & 5 & box & 2400 & 36 & 36 & 0.59 & 21.24 & 21.24 \\
\hline & & TIMATION & DTAL CARB & MISSIO & ER HOUSE & $\mathrm{O}_{2}$ eq per 1 & & & $42,523.33$ & $40,393.72$ \\
\hline
\end{tabular}




\section{REFERENCES}

[1] US Environmental Protection Agency. Inventory of U.S. Greenhouse Gas Emissions and Sinks: 1990-2018. Washington: Environmental Protection Agency, 2019.

[2] S. Natarajan, J. Padget, L. Elliott, Modelling UK domestic energy and carbon emissions: an agent-based approach Energy Build., Vol. 43, pp. 2602-2612, 2011.

[3] M. Yu, T. Wiedmann, R. Crawford \& C. Tai, The Carbon Footprint of Australia's Construction Sector, International High- Performance Built Environment Conference - A Sustainable Built Environment Conference 2016 Series (SBE16), iHBE 2016, Procedia Engineering 180, 211-220, 2017.

[4] U. Surahman, T. Kubota \& O. Higasi, Life Cycle Assessment of Energi and $\mathrm{CO}_{2}$ Emissions for Residential Buildings in Jakarta and Bandung, Indonesia. Buildings, 5, 1131-1155, 2015.

[5] P. Sudjono \& C.O. Yudhi, Estimation Of $\mathrm{Co}_{2}$ Emission From Development Of Various Sizes Of Low-Cost House, Jurnal Teknik Lingkungan, Vol. 17, No. 2, pp. 98-109, 2011.

[6] GBI, 2010. GBI Assessment Criteria for NRNC. Green Building Index Sdn. Bhd: April 2012.

[7] M.M.A. Klufallah, M. F. Nuruddin, M. F. Khamidi, N. Jamaludin, Assessment of Carbon Emission Reduction for Buildings Projects in Malaysia-A Comparative Analysis, Emerging Technology for Sustainable Development Congress (ETSDC 2014), E3S Web of Conferences, Vol. 3, pp. 1-8, 2014.

[8] Green Building Council Indonesia, Greenship Homes Version 1.0, Direktorat Pengembangan Perangkat Penilaian GBCI, 2014.

[9] S.A.K.A. Uda, M.A. Wibowo, J.U.D. Hatmoko, Optimization of Embodied Energy in Bridge Construction, Civil Engineering and Architecture, Vol. 8, No. 6, pp. 1167 - 1177, 2020. DOI: 10.13189/cea.2020.080602.

[10] Atmaca, Carbon Footprint Analysis of a Residential Building, UEMK 2019 Proceedings Book, 24/25 October 2019 Gaziantep University, pp. 866-879 Turkey, 2019.

[11] S A K A Uda, M A Wibowo, and J U D Hatmoko, Life Cycle Energy (LCE) on Project Life Cycle (PLC): a literature review, The 5th International Conference on Climate Change 2020, IOP Conf. Series: Earth and Environmental Science 724, 012057, pp. 1-8, 2021.

[12] J. Basbagill, F. Flager, M. Lepech, M. Fischer, Application of life cycle assessment to early-stage building design for reduced embodied environmental impacts. Build. Environ. Vol 60, pp. 81-92, 2013

[13] K. Chen, W. Lu, Y. Peng, S. Rowlinson, G.Q. Huang, Bridging BIM and building: from a literature review to an integrated conceptual framework. Int. J. Proj. Manag. 33 (6), pp. 1405-1416., 2015.

[14] X. Yang, M. Hu, J. Wu, B. Zhao,
Building-information-modeling enabled life cycle assessment, a case study on carbon footprint accounting for a residential building in China. J. Clean. Prod., 183, pp. 729-743, 2018.

[15] C. Peng, Calculation of a building's life cycle carbon emissions based on Ecotect and building information modelling, Journal of Cleaner Production, vol 11, pp.453-465, 2016.

[16] J. Wang, H. Wu, H. Duan, G. Zillante, J. Zuo, H. Yuan, Combining Life Cycle Assessment and Building Information Modelling to Account for Carbon Emission of Building Demolition Waste: A Case Study, Journal of Cleaner Production 172, pp. 3154-3166, 2018.

[17] H.P.V. Putten, M.A. Rocha, Estimating Carbon Dioxide Emission Reduction by Waste Minimization in Civil Construction through the Use of BIM Methodology; CAPES: Oslo, Norway, 2016.

[18] B. Hardin and D. McCool, BIM and Construction Management; Wiley Publishing, Inc.: Hoboken, NJ, USA, 2015.

[19] E.M. Elias and C.K. Lin, Empirical Study of Green Buildins (residential) implementation: perspencive of house developers, Procedia Environmental Science 28, pp. 708-716, 2015.

[20] S.Y. C. Yim, S. Thomas Ng, M. U. Hossain, J. M. W. Wong, Comprehensive Evaluation of Carbon Emissions for The Development of High-Rise Residential Building, Buildings 8, 147, Pp. 1-19, 2018.

[21] J.G. Rogers, S.J.G. Cooper, Á. O'Grady, M.C. McManus, H.R. Howard, G.P. Hammond, the $20 \%$ house - An integrated assessment of options for reducing net carbon emissions from existing UK houses, Applied Energy, vol. 138, pp. 108-120, 2015.

[22] Kong, H. Kang, S. He, N. Li, and W. Wang, Study on The Carbon Emissions in The Whole Construction Process of Prefabricated Floor Slab, Appl. Sci., Vol. 10, 2326, pp. $1-14 ; 2020$.

[23] W. Z. Taffese, and K. A. Abegaz, Embodied Energy and $\mathrm{CO}_{2}$ Emissions of Widely Used Building Materials: The Ethiopian Context, Buildings, Vol. 9, 136, pp. 1-15, 2019.

[24] S.H. Cho and C.U. Chae, A Study on Life Cycle $\mathrm{CO}_{2}$ Emissions of Low-Carbon Building in South Korea, Sustainability, Vol. 8, 579; pp. 1 - 19,2016.

[25] K. Lu, X. Jiang, V. W. Y. Tam, M. Li, H. Wang, B. Xia and Q. Chen, Development of A Carbon Emissions Analysis Framework Using Building Information Modeling and Life Cycle Assessment for The Construction of Hospital Projects, Sustainability, 11, 6274, pp. 1-18, 2019.

[26] Z. Luo and Y. Lu, Multi-case study on the carbon emissions of the ecological dwellings in cold regions of China over the whole life cycle, Energy Exploration \& Exploitation, Vol. 38(5), pp. 1998-2018, 2020

[27] S. K. Uda, L. Hein, A. Adventa, Towards better use of Indonesian peatlandswith paludiculture andlow-drainage food crops, Wetlands Ecol Manage, Vol. 28, pp. 509-526, 2020.

[28] A.A. W Mahmod, S.Mohd, M. I. M. Masirin, S. A. A. 
Tajudin, I. Bakar, A. Zainorabidin, A. Z. Kifli and L. J. Hua, Construction of Buildings on Peat: Case Studies and Lessons Learned, The $3^{\text {rd }}$ International Conference on Civil and Environmental Engineering for Sustainability (IConCEES 2015), MATEC Web of Conferences,Vol. 47, pp. 1-5, 2016.

[29] V. Muroby, C. A. Makarim, Design alternative on peat soil, 3rd TICATE 2020, IOP Conf. Series: Materials Science and Engineering 1007, 012178, 2020.

[30] X. Wang, X. Cao, H. Xu, S. Zhang, Y. Gao, Z. Deng, J. Li, Research on the properties of peat soil and foundation treatment technology, E3S Web of Conferences 272, 02019, pp. 1-4,2021.

[31] L.J. Hua, A. S. Mohd, S. A. A. Tajudin, S. N.A. Mohamad, I. Bakar, M. I. M. Masirin, A. Zainorabidin and A. A. W. Mahmood, Construction of Infrastructure on Peat: Case Studies and Lessons Learned, MATEC Web of Conferences,Vol. 47, pp. 1-6, 2016.

[32] Z. V. Gaile, T. Teppand, M. Kriipsalu, M. Krievans, Y. Jani, M. Klavins, R. H. Setyobudi, I. Grinfelde, V. Rudovica, T. Tamm, M. Shanskiy, E. Saaremae, I. Zekker and J. Burlakovs, Towards Sustainable Soil Stabilization in Peatlands: Secondary Raw Materials as an Alternative, Sustainability, vol. 13, 6726, pp. 1-24, 2021.

[33] Minister For Public Works and Human Settlements Republic Indonesia (Kemen PUPR), Hingga Pertengahan Desember 2020 Realisasi Program Sejuta Rumah Capai 856.758 Unit (Until Mid-December 2020 Realization of One Million Houses Program Reaches 856,758 Units), Public Communication Bureau of the Ministry of PUPR Indonesia, 2020.
[34] W.Supriyati, T.A. Prayitno, Sumardi, S.N. Marsoem, Local Wisdom of Utilization of Gelam Wood on Peatswamp Land of Central Kalimantan, J. Manusia Dan Lingkungan, Vol. 22, No.1, pp. 94-99, 2015.

[35] G.P. Hammond \& C.I. Jones, Inventory Karbon \& Energi (ICE) version 1.6a. Sustainable Energi Research Team (SERT). Departement Mechanical Engineering, Universty of Bath, UK, pp. 1-64, 2008.

[36] G. Syngrosa, C. A. Balarasb and D. G. Koubogiannis, Embodied $\mathrm{CO}_{2}$ Emissions in Building Construction Materials of Hellenic Dwellings, International Conference on Sustainable Synergies from Buildings to the Urban Scale, SBE16, Procedia Environmental Sciences, vol. 38, pp. 500 $-508,2017$.

[37] M. Sandanayakea, W. Lokugeb, G. Zhangc, S. Setungec, Q. Thushar, Greenhouse gas emissions during timber and concrete building construction -A scenario based comparative case study, Sustainable Cities and Society, Vol. 38, pp. 91-97, 2018.

[38] L. R. Caldas, J. S. de Matos, M. Lira, P. C. de Melo, R. M. Sposto, Life Cycle carbon emissions inventory of brick masonry and light steel framing houses, Ambiente Construído, Porto Alegre, vol. 17, no. 3, pp. 71-85, 2017.

[39] R. Kumanayake, H. Luo, N. Paulusz, Assessment of material related embodied carbon of an office building in Sri Lanka. Energy and Buildings, Vol. 166, pp. 250-257, 2018.

[40] A.A. Residul, Statistik Daerah Kota Palangka Raya (Regional Statistics of Palangkaraya City) 2021, Central Bureau of Statistics of the City of Palangka Raya, Indonesia, 2021. 